\title{
Intermetallic Compounds of Gold
}

\author{
WS Rapson \\ Consultant, 43 7th Street, Houghton 2198, South Africa
}

The publication of a treatise $(1)$ and two recent papers $(2,3)$ on the attributes and applications of intermetallic compounds (IMCs) generally make it appropriate to summarize some facts relating to the IMCs of gold.

\section{GOLD - MERCURY INTERMETALLIC COMPOUNDS}

Gold dissolves readily in mercury with the formation of a range of gold-mercury IMCs (4). This has led to their application in various ways.

Thus when gravity concentrates of gold ores are agitated in contact with mercury or a mercury-coated surface, the gold may be recovered as a solution or amalgam with the mercury from which it can be separated by distilling off the mercury. Before the cyanide extraction process was developed about 100 years ago, gold was widely recovered from its ores in this way. Because of the health risks involved this amalgamation process is now normally avoided.

The use of mercury amalgam in the fire- or mercury-gilding of metal substrates has also been abandoned because of the health risks involved and the development of better methods of producing gold coatings. In the fire gilding process, the substrate metal was first 'quicked' or surface amalgamated by immersion in a solution containing potassium cyanide and mercuric nitrate and then smeared over with a pasty Au$\mathrm{Ag}$ amalgam, using a copper spatula and a brass wire brush. The mercury was then evaporated off, during which the surface becomes first matt-white and then matt-golden. Burnishing then gives a brilliant finish (5).

Because of its affinity for mercury, gold can also be used for the absorption, estimation and removal of mercury in air or in gas streams (6) and in water supplies or effluents (7).

\section{GOLD - COPPER INTERMETALLIC COMPOUNDS}

The Au-Cu phase diagram (8) reveals that $\mathrm{Au} / \mathrm{Cu}$ ordering occurs over certain ranges of temperature and composition with the formation of intermetallic compounds $\mathrm{AuCu}-\mathrm{I}, \mathrm{AuCu}-\mathrm{II}, \mathrm{AuCu}_{3}$-I and $\mathrm{AuCu}_{3}$-II. It has been extensively studied and 'much of the theory and understanding of order-disorder phenomena has grown out of extensive studies of these phases' (8).

An important consequence of the formation of these IMCs is that many alloys containing both $\mathrm{Au}$ and $\mathrm{Cu}$ also display $\mathrm{Au} / \mathrm{Cu}$ ordering. The conditions and compositions under which they do so vary with the nature and concentrations in which elements other than $\mathrm{Au}$ and $\mathrm{Cu}$ are present. The occurrence of $\mathrm{Au} / \mathrm{Cu}$ ordering under certain conditions is therefore an important feature of both yellow and white carat golds and of many dental gold alloys. It determines their behaviour on heat treatment and for some alloy compositions of these types is more important than phase separation in age-hardening of the alloys. Moreover, with certain alloy compositions, ordering is accompanied by martensitic transformations (9). Recognition of this in the case of certain Au-Al-Cu alloys is relatively recent and its full potential in the production of carat gold alloys with spangling properties is being explored. Shape memory properties are a feature of these alloys (9).

\section{GOLD - ALUMINIUM INTERMETALLICS}

The Au-Al IMCs derive their importance from the fact that their formation poses a continuing problem in electronic devices in which bonds are formed between $\mathrm{Al}$ wire and $\mathrm{Au}$ surfaces or $\mathrm{Au}$ wire and $\mathrm{Al}$ surfaces (10). Such bonds may fail if the devices are exposed to temperatures at which interfacial diffusion rates are high. Failure of such bonds is due to formation of the brittle purple compound $\mathrm{Al}_{11} \mathrm{Au}_{6}$ ('purple plague') and/or from differential diffusion rates across the 
interface and the formation of interfacial or Kirkendall voids at the interface.

Attempts to use the purple $\mathrm{Al}_{11} \mathrm{Au}_{6}$ intermetallic as a jewellery alloy (illustrated in the form of a pendant in the Figure below) have been frustrated by its brittleness but it is now finding commercial application in the form of inset gemstones. Coincidentally, the composition equates to an 18 carat gold material. The intensity of its colour is greatly weakened by the addition of other metals. Ga and In also form coloured IMCs with gold, but their colours are weak and they suffer from the same disadvantages as $\mathrm{Al}_{11} \mathrm{Au}_{6}$.

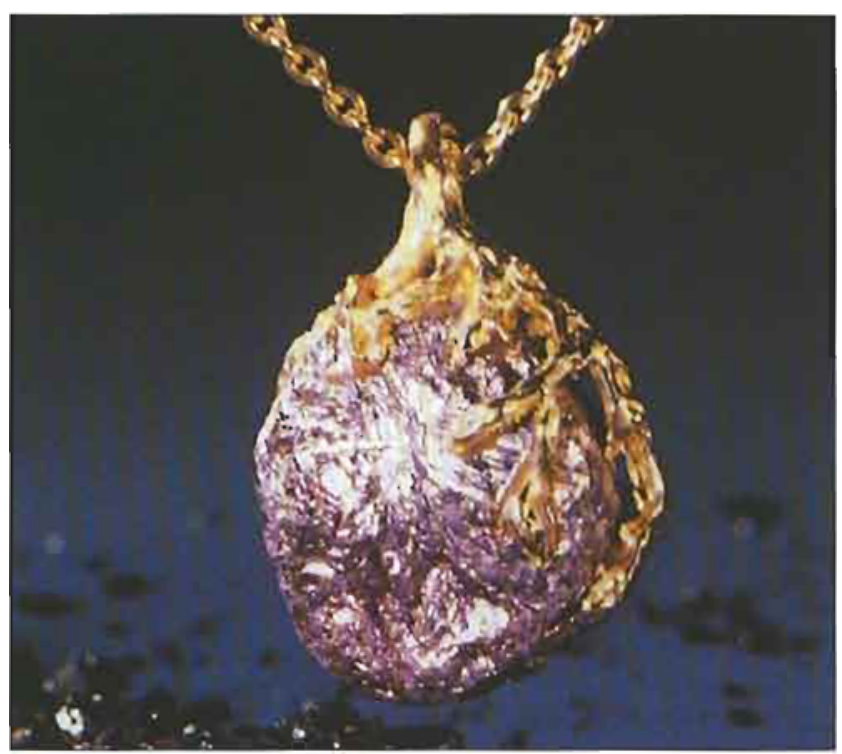

\section{GOLD - TIN INTERMETALLIC COMPOUNDS}

Gold and tin form a series of Au/Sn IMCs of which the best known is $\mathrm{AuSn}_{4}$. Its formation is to be avoided when bonds are established to gold-coated surfaces using tin-based solders by keeping gold thicknesses and therefore gold concentrations in the soldered joints to a minimum (11).

\section{GOLD - TITANIUM INTERMETALLIC COMPOUNDS}

Of these the IMC TiAu, is best known because its formation was exploited in the development of the high(23.76) caratage gold-1\% titanium alloy ('990' gold) used in jewellery and watchcase manufacture (12). The titanium forms $\mathrm{TiAu}_{4}$ which acts as a precipitation hardening agent when it separates during heat treatment of the alloy below about $800^{\circ} \mathrm{C}$.
Using appropriate technology, this hardening effect has led to the production of high strength gold bonding wires and gold foil (13).

Finally, it is appropriate to recall that shape memory properties were first observed in an Au-Cd alloy and that $\mathrm{Au}-\mathrm{Cu}-\mathrm{Zn}$ alloys have been studied from this point of view. The formation of martensitic phases of IMCs is a feature of these alloys as it is of the Au-Al-Cu alloys referred to above.

\section{REFERENCES}

1 'Intermetallic Compounds: Principles and Practice', ed. J.H. Westbrook and R.L. Fleischer, John Wiley and Sons Ltd., Chichester, UK, 1994

2 J.H. Westbrook, MRS Bulletin, 1996, 21, 37

3 L. McD. Schetky, MRS Bulletin, 1996, 21, 50

4 H. Okamoto and T.B. Massalski, in 'Phase Diagrams of Binary Gold Alloys', ASM International, 1987, 132

5 W.S. Rapson and (in part) T. Groenewald, 'Gold Usage', Academic Press, London, 1978, p. 286

6 M.A. Butler, A.J. Ricco and R.J. Baughman, $J$. Appl. Phys., 1990, 67 (Part 1), 4320; C. Barghigiami, T. Ristori and M. Cortopassi, Environ. Technol., 1991, 12, 135; P.B. Stockwell, P. Rabl and M. Paffrath, Proc. Control. Qual., 1991, 1, 293; J.J. McNerney and P.R. Busack, Econ. Geol., 1973, 68, 1313

7 S. Akabori et al, Jpn. Kokai, 1975, 75.67275; H.G. Robinson and M.S. Shuman, Int. J. Environ. Anal. Chem., 1989, 36, 111-123; T. Hentschel and M. Priester, Erzmetall., 1990, 43, 331

8 H. Okamoto, T.B. Massalski; D.J. Chakrabarti and D.E. Laughlin, in 'Phase Diagrams of Binary Gold Alloys', ASM International, 1987, 76

9 I.M. Wolff and M.B. Cortie, Gold Bull., 1994, 27 (2), 44. G.B. Brook and R.F. Iles, Gold Bull., $1975,8,16$

10 T. Raymond, Semiconductor Int., 1989, 12, 152

11 C.J. Thwaites, Electroplat. Met. Finish., 1973, 26, 10 and 21; H. Heinzel and K.E. Saeger, Gold Bull., $1976,9,7$

12 G Gafner, Gold Bull., 1989, 22, 112

13 G. Humpston and D.M. Jacobson, Gold Bull., 1992, 25, 132 